\title{
Unresponsiveness to skin testing with bacterial antigens in patients with haemophilia A not apparently infected with human immunodeficiency virus (HIV)
}

\author{
R A SHARP,* S M MORLEY, $\dagger$ J SWANSON BECK, $†$ G E D URQUHART $\ddagger$ \\ From the Departments of *Haematology, †Immunology, and $\ddagger$ Virology, Ninewells Hospital and Medical School, \\ Dundee, Scotland
}

SUMMARY Unresponsiveness to skin testing with PPD and tetanus toxoid was commonly seen in patients with haemophilia A but not infected with human immunodeficiency virus but was uncommon in controls. Vaccination history indicated that the unresponsive patients had not been immunised in childhood. Other tests of immune competence (skin tests with other antigens, lymphocyte stimulation with mitogens and antigens, and viral serology) showed that the haemophilia $\mathrm{A}$ patients had an adequate response to pathogens to which they had been exposed. Five of 12 such patients had a mild T4 lymphopenia, and this may have been related to parenteral administration of large quantities of protein.

The acquired immune deficiency syndrome (AIDS) is now widespread in patients with haemophilia (type A more than type B) due to contamination of blood products with human immunodeficiency virus (HIV). ${ }^{12}$ Those infected in this way showed anti-HIV antibodies in their serum, ${ }^{3}$ T4 lymphopenia, ${ }^{4}$ and cutaneous anergy similar to that seen in patients infected by other routes. ${ }^{5} \mathrm{~T} 4$ lymphopenia and diminished responsiveness to dinitrochlorobenzene sensitisation occur in such patients not infected with HIV, and it is thought that repeated administration of large amounts of factor VIII or cryoprecipitate may itself be immunosuppressive. ${ }^{6}$

In this study apparent cutaneous anergy to commonly encountered bacterial antigens in some haemophilia A patients reflects lack of prophylactic immunisation rather than immunosuppression: other assessments of immune function were apparently normal.

\section{Material and methods}

Fifteen patients with factor VIII deficiency (12 with haemophilia $\mathbf{A}$ and three with von Willebrand's disease) and five patients with factor IX deficiency were

Accepted for publication 14 April 1987 studied, along with 12 healthy controls. The study group included more than $95 \%$ of the haemophilia patients in the Tayside Region. All patients were treated exclusively with blood products prepared in the Scottish National Blood Transfusion Service Fractionation Centre in Edinburgh. None received treatment from batches now known to have been contaminated with HIV. ${ }^{7}$ Vaccination history, clinical assessment, erythrocyte, leucocyte and platelet counts were obtained at the onset of the study in 1985: total lymphocyte, monocyte, and granulocyte counts were calculated after differential counts on the blood films. Lymphocyte subsets were counted by flow cytofluorimetry after staining with CD4 and CD8 monoclonal antibodies. ${ }^{8}$

Skin tests with the Multitest CMI applicator (Merieux UK Ltd, Slough) and a standard Mantoux test (with $0.1 \mathrm{ml}$ "new tuberculin"9) were performed on all subjects. The mean diameter of the response at 48 hours (induration only) was recorded: reactions of $>2 \mathrm{~mm}$ were regarded as positive.

Lymphocyte stimulation tests were performed separately ${ }^{10}$ with phytohaemagglutinin (HA16, Wellcome Diagnostics, Dartford), Concanavalin A (grade IV, Sigma Chemical Company, Dorset) and pokeweed mitogen (061-5360B, Gibco, Paisley), and with tuberculin PPD (Evans Medical Ltd, Beaconsfield) 
Table Skin test results and immunisation history of patients with congenital disorders of blood coagulation and healthy controls

\begin{tabular}{|c|c|c|c|c|c|c|c|c|}
\hline \multirow[b]{2}{*}{ Group } & \multirow[b]{2}{*}{ Age } & \multirow[b]{2}{*}{$\operatorname{Sex}$} & \multirow{2}{*}{$\begin{array}{l}\text { Plasma } \\
\text { concentrations } \\
\text { of factor VIII/IX } \\
(I U / d l)\end{array}$} & \multirow{2}{*}{$\begin{array}{l}\text { Supplement } \\
\text { of factor } \\
\text { VIII/IX }\end{array}$} & \multicolumn{3}{|c|}{ Immunisation history } & \multirow{2}{*}{ 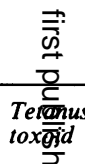 } \\
\hline & & & & & $B C G$ & Polio & $\begin{array}{l}\text { Triple } \\
\text { vaccine }\end{array}$ & \\
\hline Haemophilia A & $\begin{array}{l}23 \\
38 \\
72 \\
54 \\
66 \\
38 \\
14 \\
18 \\
18 \\
21 \\
17 \\
28\end{array}$ & $\begin{array}{l}\mathbf{M} \\
\mathbf{M} \\
\mathbf{M} \\
\mathbf{M} \\
\mathbf{M} \\
\mathbf{M} \\
\mathbf{M} \\
\mathbf{M} \\
\mathbf{M} \\
\mathbf{M} \\
\mathbf{M} \\
\mathbf{M}\end{array}$ & $\begin{aligned} & 19 \\
& 2 \\
& 7 \cdot 5 \\
< & 3 \\
< & 1 \\
< & 1 \\
< & 1 \\
< & 1 \\
< & 1 \\
< & 1 \\
& 42\end{aligned}$ & $\begin{array}{l}+ \\
+++ \\
+ \\
++ \\
++ \\
++ \\
++ \\
++ \\
+++ \\
++ \\
+ \\
+\end{array}$ & $\begin{array}{l}\text { Yes } \\
\text { No } \\
\text { No } \\
\text { No } \\
\text { No } \\
\text { No } \\
\text { No } \\
\text { Yes } \\
\text { No } \\
\text { Yes } \\
\text { Yes } \\
\text { Yes }\end{array}$ & $\begin{array}{l}\text { Yes } \\
\text { No } \\
\text { No } \\
\text { No } \\
\text { No } \\
\text { No } \\
\text { Yes } \\
\text { Yes } \\
\text { No } \\
\text { Yes } \\
\text { Yes } \\
\text { Yes }\end{array}$ & $\begin{array}{l}* \\
\text { No } \\
\text { No } \\
\text { No } \\
\text { No } \\
* \\
\text { Yes } \\
\text { No } \\
\text { No } \\
\text { Yes } \\
\text { Yes } \\
\text { Yes }\end{array}$ & $\begin{array}{l}\text { Yeß口 } \\
\text { NoO } \\
\text { No" } \\
\text { No- } \\
\text { No:- } \\
\text { No= } \\
\text { Yes్ } \\
\text { * S } \\
\text { YeS } \\
\text { Yes } \\
\text { Yes } \\
\text { Yes }\end{array}$ \\
\hline Haemophilia B & $\begin{array}{l}29 \\
26 \\
23 \\
36 \\
17\end{array}$ & $\begin{array}{l}\mathbf{M} \\
\mathbf{M} \\
\mathbf{M} \\
\mathbf{M} \\
\mathbf{M}\end{array}$ & $\begin{aligned}< & 1 \\
& 2 \\
& 2 \cdot 5 \\
< & 2 \\
< & 1\end{aligned}$ & $\begin{array}{l}++ \\
++ \\
+ \\
+ \\
++\end{array}$ & $\begin{array}{l}\text { No } \\
\text { No } \\
\text { Yes } \\
\text { Yes }\end{array}$ & $\begin{array}{l}\text { Yes } \\
\text { Yes } \\
\text { Yes } \\
\text { Yes } \\
\end{array}$ & $\begin{array}{l}\text { Yes } \\
\text { Yes } \\
\text { Yes } \\
\text { Yes } \\
{ }^{*}\end{array}$ & $\begin{array}{l}\text { No } \\
\text { Yeso } \\
\text { Yeso } \\
\text { Yes } \\
*-\end{array}$ \\
\hline $\begin{array}{l}\text { von Willebrand's } \\
\text { disease }\end{array}$ & $\begin{array}{l}47 \\
21 \\
17\end{array}$ & $\begin{array}{l}\mathbf{F} \\
\mathbf{F} \\
\mathbf{M}\end{array}$ & & $\begin{array}{l}+ \\
+\end{array}$ & $\begin{array}{l}\text { Yes } \\
\text { Yes } \\
\text { No }\end{array}$ & $\begin{array}{l}\text { Yes } \\
\text { Yes } \\
\text { No }\end{array}$ & $\begin{array}{l}\text { Yes } \\
\text { Yes } \\
\text { No }\end{array}$ & $\begin{array}{l}\text { Ye⿳亠口冋 } \\
\text { Yesn } \\
\text { No- }\end{array}$ \\
\hline Controls & $\begin{array}{l}53 \\
35 \\
41 \\
33 \\
28 \\
26 \\
51 \\
21 \\
21 \\
22 \\
20 \\
25\end{array}$ & $\begin{array}{l}\mathbf{M} \\
\mathbf{M} \\
\mathbf{M} \\
\mathbf{M} \\
\mathbf{M} \\
\mathbf{M} \\
\mathbf{F} \\
\mathbf{F} \\
\mathbf{F} \\
\mathbf{M} \\
\mathbf{M} \\
\mathbf{M}\end{array}$ & & & $\begin{array}{l}\text { Yes } \\
\text { Yes } \\
\text { Yes } \\
\text { Yes } \\
\text { Yes } \\
\text { Yes } \\
\text { Yes } \\
\text { Yes } \\
\text { Yes } \\
\text { Yes } \\
\text { Yes } \\
\text { Yes }\end{array}$ & $\begin{array}{l}\text { Yes } \\
\text { Yes } \\
\text { Yes } \\
\text { Yes } \\
\text { Yes } \\
\text { Yes } \\
\text { Yes } \\
\text { Yes } \\
\text { Yes } \\
\text { Yes } \\
\text { Yes } \\
\text { Yes }\end{array}$ & $\begin{array}{l}\text { Yes } \\
\text { Yes } \\
\text { Yes } \\
\text { Yes } \\
\text { Yes } \\
\text { Yes } \\
\text { No } \\
\text { Yes } \\
\text { Yes } \\
\text { Yes } \\
\text { Yes } \\
\text { Yes }\end{array}$ & 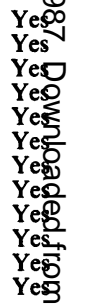 \\
\hline
\end{tabular}

"History “don't know”, but skin tests positive.

Coagulation factor consumption:,$+<10000 \mathrm{IV}$, p.a;,$++ 10000-40000 \mathrm{IU}$ p.a;,$+++>40000 \mathrm{IU}$ p.a.

and Candida extract (Merieux UK Ltd). The cultures were pulsed for four hours with ${ }^{3} \mathrm{H}$-thymidine, starting at 68 hours for mitogen and at 116 hours for antigen stimulation.

HIV antibodies were assayed in 1985 by radioimmunoassay and in 1986 by enzyme linked immunosorbent assay (Organon Teknika, Cambridge). Other investigations on serum samples included hepatitis B surface antigen and antibodies; anti-HBc and anti-HBs (both EIA, Abbot Laboratories, Wokingham); cytomegalovirus (CMV) herpes simplex and herpes zoster antibodies complement fixation test ${ }^{11}$; IgG and IgM antibodies to EpsteinBarr virus capsid (immunofluorescence); and Toxoplasma gondii antibodies.

Results were analysed by paired and unpaired $t$ tests as appropriate.

\section{Results}

Patients with haemophilia A had fewer positive reac- tions to "old tuberculin" and tetanus toxoid and ? more positive reactions to Proteus mirabilis with the Multitest applicator, and fewer positive Mantoux tests than the other patients or the controls. Positive responses were of comparable size in all groups (table). Vaccination history showed that virtually all 윽 controls and patients with haemophilia B or von $D$ Willebrand's disease had received "triple vaccine", tetanus toxoid, and BCG immunisation, whereas only o four of the 12 patients with haemophilia A were fully vaccinated (table).

No difference was found in the total lymphocyte or $\mathrm{C}$ T8 cell count between the groups. The mean T4 lym- phocyte count in haemophilia A patients was lower 0 than that in haemophilia B patients or controls $\Phi$ (figure) $(\mathrm{p}<0.005)$. Those haemophilia A patients $\stackrel{?}{+}$ with T4 lymphocyte counts of $<1.0 \times 10^{9} \mathrm{~g} / 1$ had as 70 many positive skin test reactions as the other patients with this disease. Lymphocyte stimulation tests $\bigcirc$ showed no difference in response between the patient $\stackrel{\AA}{\unrhd}$ groups and controls. 


\begin{tabular}{|c|c|c|c|c|c|c|c|}
\hline \multirow[b]{2}{*}{ Tetanus toxoid } & \multicolumn{6}{|c|}{ Multitest CMI } & \multirow{2}{*}{$\begin{array}{l}\text { Intradermal } \\
\text { infection } \\
\text { "new } \\
\text { tuberculin" }\end{array}$} \\
\hline & $\begin{array}{l}\text { Diphtheria } \\
\text { toxoid }\end{array}$ & $\begin{array}{l}\text { Streptococcus } \\
\text { antigen }\end{array}$ & $\begin{array}{l}\text { Old } \\
\text { tuberculin }\end{array}$ & $\begin{array}{l}\text { Candida } \\
\text { antigen }\end{array}$ & $\begin{array}{l}\text { Trichophyton } \\
\text { antigen }\end{array}$ & $\begin{array}{l}\text { Proteus } \\
\text { antigen }\end{array}$ & \\
\hline & 3 & 3 & 5 & 2 & - & 2 & 10 \\
\hline & 5 & - & $\bar{z}$ & 3 & $\overline{2}$ & 3 & 二 \\
\hline & - & - & 1 & - & - & 1 & - \\
\hline & $\begin{array}{l}4 \\
3.5\end{array}$ & 2.5 & 3.5 & $\begin{array}{l}4 \\
2.5\end{array}$ & E & $\overline{3}$ & $\bar{z}$ \\
\hline , & 6 & - & - & 4 & - & 3 & - \\
\hline '. & $\overline{-}$ & $\bar{z}$ & 4 & 4 & $=$ & $\overline{7}$ & $\underline{4}$ \\
\hline , & - & 5 & 4 & 3 & - & 1.5 & - \\
\hline$\vdots$ & $\begin{array}{l}2 \\
3\end{array}$ & $\overline{2}$ & $\underline{6}$ & 4 & 5.5 & 二 & $\begin{array}{l}6 \cdot 5 \\
3\end{array}$ \\
\hline & 3 & 4 & 4.5 & - & - & - & - \\
\hline i & 3 & 5 & $\overline{4}$ & $\overline{3}$ & $\overline{2}$ & $\begin{array}{l}3.5 \\
4\end{array}$ & $\overline{10}$ \\
\hline 1 & 8 & 3 & $\begin{array}{l}4 \\
8\end{array}$ & 5 & 2 & - & 20 \\
\hline \multirow[t]{10}{*}{.5} & 2 & - & 4.5 & 2 & 1 & - & 15 \\
\hline & - & - & 10 & 7 & - & - & 12 \\
\hline & - & 2 & $\overline{-}$ & 6 & $\overline{-}$ & - & $\underline{5}$ \\
\hline & 4 & 3 & 12 & 4 & - & - & 14 \\
\hline & - & $?$ & 2 & 4 & 4 & $\begin{array}{l}3 \\
3\end{array}$ & 10 \\
\hline & 3 & 2 & $\begin{array}{l}9 \\
7\end{array}$ & $\begin{array}{l}3 \\
6\end{array}$ & $\begin{array}{l}3 \\
3\end{array}$ & 3 & 10 \\
\hline & 5 & 4 & 5 & 1 & 3 & $=$ & 5 \\
\hline & 2 & 4 & 5 & 5 & - & 4 & 10 \\
\hline & - & 二 & 4 & 3 & - & - & - \\
\hline & E & $\overline{2}$ & $\begin{array}{r}4 \\
10\end{array}$ & 3 & $\bar{z}$ & $\bar{z}$ & $\overline{11}$ \\
\hline$\cdot 5$ & 3 & - & 7 & 5 & 4.5 & - & 7 \\
\hline & 2 & $\overline{2.5}$ & ${ }_{5}^{6} .5$ & 2 & - & - & 5 \\
\hline
\end{tabular}

No correlation was found between either endogenous factor VIII values, or the dose of therapeutic concentrate required for disease control and T4 lymphocyte count, or lymphocyte stimulation test responses.

The antibody titres to cytomegalovirus, herpes simplex, herpes zoster and Toxoplasma in the patients with inherited coagulation defects were not significantly different from those in the controls. Twelve of the 20 patients had antibodies to HBs and $\mathrm{HBc}$ as did one of the controls. All controls had positive tests for IgG antibody specific for Epstein-Barr virus (EBV) but were negative to IgM antibody (indicating past infection). Of the 16 patients with IgG antibodies to EBV, six also gave a positive test for IgM antibodies (suggesting initially that these patients had active infection), but these results must be regarded as false positives as the sera became negative after absorption with aggregated human IgG. It is therefore likely that the false positive results were due to the presence of "rheumatoid factor" or related
IgM class anti-IgG antibody.

Tests for antibody to HIV were performed in 1985 on serum samples removed at the time of skin testing (radioimmunoassay by Dr RS Tedder) and samples removed one year later, 1986 (ELISA). All these serum samples were negative for anti-HIV.

\section{Discussion}

The absence of skin test responses in the group with haemophilia A occurred in those patients who had not been vaccinated and with those antigens generally only encountered at immunisation. Skin test responses to other antigens were comparable in all groups. Thus the non-reactors were not immunosuppressed, merely unimmunised. The reason why they did not receive immunisation cannot be established at this late date. It may have been due to the natural desire of the parents to protect them from trauma.

The serological studies suggest that all the patients 


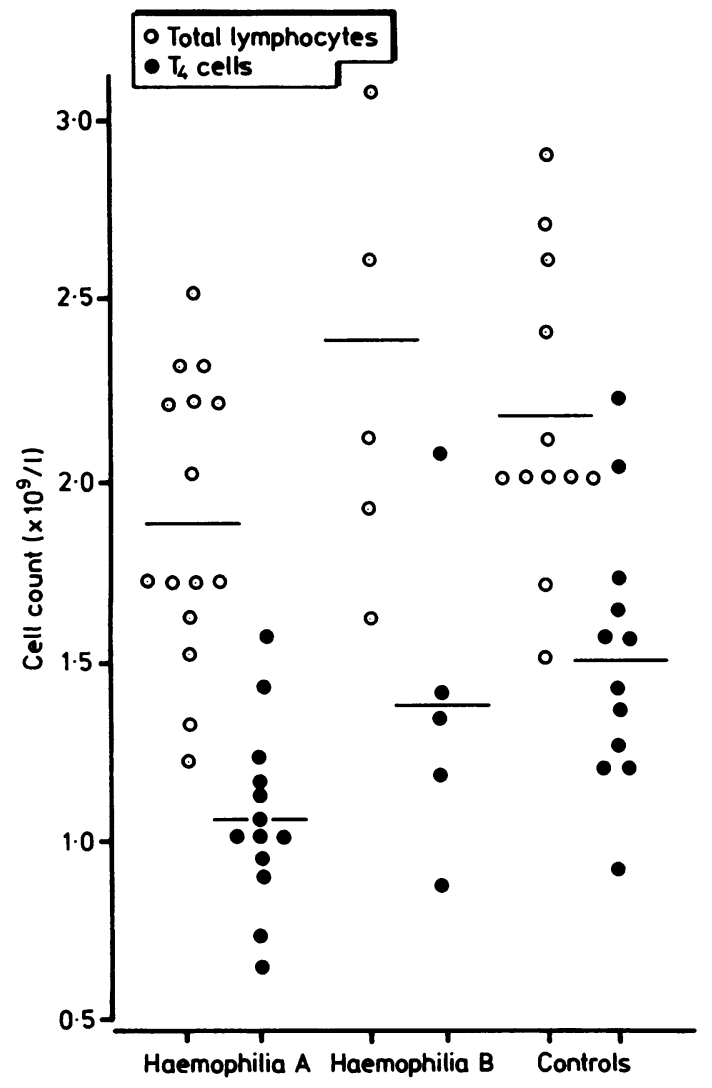

Figure Total lymphocyte counts (open circles) and T4 lymphocyte counts (solid circles) in patients with haemophilia A, haemophilia B, and in healthy controls.

responded to common pathogens by specific antibody production. The high prevalence of antibodies to hepatitis B virus indicates an appropriate humoral response to the frequent contamination of coagulation factor concentrates with virus antigen. It is important to note the high prevalence of false positive results in the tests for IgM antibodies to EBV, lest an incorrect assumption be made of persisting or reactivation of EBV infection.

Five of the 12 haemophilia A patients showed some degree of lymphopenia. All had been treated with factor VIII concentrate that can be assumed to have been free from contamination with HIV; none had evidence of antibody to this virus either at the time of immunological study or more than one year later.
This accords with other studies of haemophilia $\mathrm{A} \stackrel{\bullet}{\vec{\sigma}}$ patients not infected with HIV where T4 lympho- 으․ penia has been attributed to large quantities of factor VIII per se. ${ }^{6}$

This study shows that in this group of patients apparent cutaneous anergy should be interpreted with $\frac{\bar{O}}{\bar{N}}$ caution as it may reflect non-immunisation rather than immunosuppression.

We are grateful to Dr RS Tedder for testing the sera in 1985 for anti-HIV and to Dr JH Gibbs and Mr RC. Potts for performing the lymphocyte stimulation $\vec{\omega}$ tests; the "new tuberculin" and Multitest applicators were gifts from Dr JL Stanford and Merieux UK Ltd, 응 respectively; Mrs R Mitchell gave us valuable secre- $\overrightarrow{0}$ tarial help.

\section{References}

1 Centre for Disease Control, Atlanta. Pneumocystis carinii pneumonia amongst patients with hemophilia A. $M M W R$ 1982;31:365-7.

2 Curran JW, Lawrence DN, Jaffe H, et al. Acquired $\frac{C}{\omega}$ immunodeficiency syndrome (AIDS) associated with transfusions. N Engl J Med 1984;310:69-75.

3 AIDS group of haemophilia centre directors. Prevalence of antibody to HTLV-III in haemophiliacs in the United Kingdom. Br Med J 1986;293:175-6.

4 Anonymous. Blood transfusion, haemophilia and AIDS. [Editorial]. Lancet 1984;ii:1433-6.

5 Evatt BL, Ramsey RB, Lawrence DN, et al. The acquired immunodeficiency syndrome in patients with hemophilia. Ann 을 Intern Med 1984;100:499-504.

6 Madhok R, Gracie A, Lowe GDO, et al. Impaired cell mediated $\vec{a}$ immunity in haemophilia in the absence of infection with 윽 human immunodeficiency virus. $\mathrm{Br}$ Med J 1986;293:978-80.

7 Ludlam CA, Tucker J, Steel CM, et al. Human T-? lymphocytotrophic virus type III (HTLV-III) infection in seronegative haemophiliacs after transfusion of factor VIII. Lancet 1985;i1:233-6.

8 Roberts C, Potts RC, Brown RA, et al. The sensitivity of peripheral blood lymphocytes to growth inhibition by hydrocortisone 3 is not determined by their OKT4:OKT8 ratio. Immunol Lett 1983;6:227-30.

9 Shield MJ, Stanford JL, Paul RC, Carswell JW. Multiple skin 3 testing of tuberculosis patients with a range of new tuberculins $O$ and a comparison with leprosy and Mycobacterium ulcerans infection. J Hyg (Lond) 1977;78:331-48.

10 Gibbs JH, Robertson AJ, Brown RA, et al. Mitogen-stimulated lymphocyte growth and chronic uraemia. J Clin Lab Immunol $\mathrm{N}$ 1982;9:19-25.

11 Bradstreet CPM, Taylor CED. Technique of complement- $N$ fixation test applicable to the diagnosis of virus diseases. O Monthly Bulletin Ministry of Health Public Health Laboratory $W$ Service 1962;21:96-104.

Requests for reprints to: Professor J Swanson Beck, Pathol- $-\frac{O}{C}$ ogy Department, Ninewells Hospital and Medical School, $\mathbb{D}$ Dundee, PO Box 120, Dundee DD1 9SY, Scotland. 